\title{
PEMBAGIAN HARTA WARIS ADAT LAMPUNG SAI BATIN KABUPATEN PESISIR BARAT PERSPEKTIF HUKUM ISLAM
}

\author{
Kusnadi \\ Pegawai KUA Kabupaten Pringsewu Provinsi Lampung \\ email : kusnadiramzi@yahoo.com
}

Diterima: 11 Mei 2017. Disetujui: 08 Oktober 2017

Dipublikasikan: November 2017

\begin{abstract}
This article discusses the analysis of Islamic law against the distribution of the community's heirs in Sai Batin Marga Pasar Krui. The system used by the native people in Sai Batin Pesisir Barat is divided into two forms: first, the native peoples in Pasar Krui use the matriarchal major division system. Women are only entitled to live in the house and manage the garden, but not to sell it. If they do not have a daughter, the boy is also allowed to get the heirs. Second, the native peoples in Way Napal use the patrilineal division system. The absolute decision is possessed by the heirs as the owner and the absolute decision-maker. To whom the treasure will be distributed and the amount of it is determined by the decision of the testator. The way used in this distribution is washiyah (will). This is because they are still hard with the customary rules and their lack of understanding of the Islamic inheritance law that part of Islamic religious rules.
\end{abstract}

Keywords: Waris, Adat Lampung Sai Batin

\section{A. Pendahuluan}

Kewarisan adalah hal yang sangat erat dan dekat dengan kehidupan manusia. Hal ini dikarenakan kewarisan adalah hal yang tidak bisa dihindarkan ketika terjadi kematian. Salah satu asas kewarisan adalah asas ijbāri yang menjelaskan 
mengenai mestinya peralihan harta dari pewaris kepada ahli waris setelah terjadi kematian. Dalam pandangan Islam kewarisan termasuk salah satu bagian dari fikih atau ketentuan yang harus dipatuhi umat Islam dan dijadikan pedoman dalam menyelesaikan harta peninggalan seseorang yang telah mati. Allah menetapkan ketentuan tentang kewarisan ini karena ia menyangkut dengan harta yang di satu sisi kecenderungan manusia kepadanya dapat menimbulkan persengketaan dan di sisi lain Allah tidak menghendaki manusia memakan harta yang bukan haknya. ${ }^{1}$

Sampai saat ini terdapat tiga sistem hukum yang mengatur tentang kewarisan yang berlaku di Indonesia, yaitu hukum waris Adat, hukum waris Islam dan hukum waris BW. Hal ini disebabkan, hingga saat ini Indonesia belum memiliki suatu unifikasi hukum waris yang bersifat nasional. Tetapi apabila sifat kekeluargaan yang ada pada waris adat, dibandingkan dengan sifat kekeluargaan yang terdapat pada orang-orang Tionghoa dan Eropa yang tunduk pada waris BW, maka ada perbedaannya, yaitu yang terpenting adalah terletak pada adanya Pasal 1066 BW yang tidak terdapat dalam hukum adat di antara orang-orang Indonesia asli. ${ }^{2}$ Pasal 1066 BW ini menentukan, adanya hak mutlak dari para ahli waris masing-masing untuk sewaktu-waktu menuntut pembagian dari harta warisan, sedangkan hukum adat di antara orang-orang Indonesia asli, harta warisan itu tidak diubah-ubah dan tidak boleh dipaksakan untuk dibagi antara ahli warisnya.

Pada masyarakat adat Lampung Pesisir yang menggunakan bentuk perkawinan jujur, memakai sistem kewarisan mayorat laki-laki, yaitu sistem kewarisan di mana anak laki-laki tertua berhak atas seluruh harta peninggalan dan sebagai penerus keturunan mereka. Begitu kuatnya

\footnotetext{
${ }^{1}$ Amir Syarifuddin, Garis-Garis Besar Fiqh, Jakarta: Prenada Media, 2005), Cet. Ke-II, h. 148.

${ }^{2} \mathrm{R}$. Wirjono Prodjodikoro, Hukum Warisan di Indonesia, Jakarta: Sumur Bandung, 1980), h. 12.
} 
kedudukan anak laki-laki dalam keluarga sehingga jika tidak mempunyai anak laki-laki dikatakan sama dengan tidak mempunyai keturunan atau putus keturunan. ${ }^{3}$ Pada masyarakat adat Lampung Pesisir, jika dalam keluarga tidak mempunyai anak laki-laki, maka dalam hukum adat masyarakat Lampung diperbolehkan untuk mengadopsi anak sebagai penerus keturunan. Ketentuan adopsi ini bisa dari anak kerabat sendiri, tetapi jika tidak ada, dapat mengadopsi anak orang lain di luar keturunan kerabatnya.

Berdasarkan data awal yang penulis peroleh setelah melakukan kegiatan pra survei, bahwa di masyarakat adat Lampung Sai Batin terdapat 16 marga yang dipimpin oleh seorang kepala yang mempunyai gelar Suntan, dari masingmasing marga membawahi 12 suku marga yang dipimpin oleh seorang kepala dengan gelar sesuai yang diberikan oleh Kepala Marga atau Suntan yaitu Kapitan, Raja dan Batin, masyarakat adat Pesisir Barat tersebar di seluruh Kecamatan dan Pekon yang ada di Kabupaten Pesisir Barat.

Pada saat peneliti melakukan kegiatan pra survei, peneliti menemukan fakta bahwa salah satu dari 16 marga yang terdapat di mayarakat adat lampung Pesisir Barat terdapat 1 marga tepatnya di Sai Batin Marga Pasar Krui, yang menggunakan pembagian harta waris dengan sistem matrilineal mayorat. Berdasarkan permasalahan tersebut, maka penulis akan membahas bagaimana sistem pembagian harta waris masyarakat adat Lampung Sai Batin Kabupaten Pesisir Barat? dan bagaimana tinjauan hukum Islam terhadap pembagian harta waris masyarakat tersebut?

\section{B. Pembahasan}

\section{Pengertian dan Dasar Hukum Kewarisan Islam}

Hukum Kewarisan Islam atau yang dalam kitab-kitab fikih biasa disebut färäid adalah hukum kewarisan yang diikuti 1978), h. 34.

${ }^{3}$ Hilman Hadikusuma, Hukum Kekerabatan Adat, Jakarta: Fajar Agung, 
oleh umat Islam dalam usaha mereka menyelesaikan pembagian harta peninggalan keluarga yang meninggal dunia. Di beberapa negara berpenduduk mayoritas beragama Islam, färäid telah menjadi hukum positif, meskipun di Indonesia hanya berlaku untuk warga negara yang beragama Islam, tidak berlaku secara nasional. Namun di beberapa negara, hukum tersebut telah menjadi hukum nasional seperti yang berlaku di Saudi Arabia.

Kata kewarisan berasal dari kata dasar waris, yang dalam

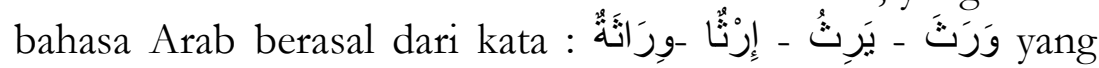
ورث فلانا " mengandung arti mewarisi, ${ }^{4}$ atau seperti kalimat "فربيه" yang artinya si fulan telah mewarisi kerabatnya atau "ورث أباه" artinya ia telah mewarisi ayahnya. ${ }^{5}$

Secara etimologi, menurut Muhammad Ali AshShabuni, waris (al-mirats), dalam bahasa Arab adalah bentuk mashdar (infinitif) dari kata waritsa-yaritsu irtsan-miratsan. Maknanya menurut bahasa ialah berpindahnya sesuatu dari seseorang kepada orang lain atau dari suatu kaum kepada kaum lain. "Kata "warits" berasal dari bahasa Arab mirats. Bentuk jamaknya adalah mawaris, yang berarti harta peninggalan orang meninggal yang akan dibagikan kepada ahli warisnya. $^{7}$

Secara terminologi terdapat beberapa perumusan, misalnya menurut Ali Ash-Shabuni ialah berpindahnya hak kepemilikan dari orang yang meninggal kepada ahli warisnya yang masih hidup, baik yang ditinggalkan itu berupa harta (uang), tanah atau apa saja yang berupa hak milik legal secara

\footnotetext{
${ }^{4}$ Mahmud Yunus, Kamus Arab-Indonesia, Jakarta: PT. Hidakarya Bandung, 1990), h. 496

${ }^{5}$ Muhammad Ali Al-Shobuni, al-Mawarits fi al-Syariat al-Islamiyyah, diterjemahkan Hamdan Rasyid, Hukum Kewarisan, Menurut Al-Qur'an dan Sunnah, (Jakarta: Dar Al-Kutub Al-Islamiyah, 2005), Cet. Ke-1, h. 39

${ }^{6}$ Muhammad Ali Ash-Shabuni, Pembagian Waris Menurut Islam, Terj. Basalamah, (Jakarta: Gema Insani Press, 1995), h. 33.

${ }^{7}$ Dian Khairul Umam, Fiqih Mawaris, (Bandung: Pustaka Setia, 2006), h. 11
} 
syar'i. ${ }^{8}$ Menurut Wahbah al-Zuhaeli sebagaimana dikutip oleh Athoilah, waris atau warisan (mirats) sama dengan makna tirkah yaitu segala sesuatu yang ditinggalkan oleh seseorang sesudah wafat, baik berupa harta maupun hak-hak yang bersifat materi dan nonmateri. ${ }^{9}$ Dari batasan tersebut dapat diperoleh ketentuan bahwa menurut hukum Islam, kewarisan baru terjadi setelah pewaris meninggal dunia. Dengan demikian, pengoperan harta kekayaan kepada yang termasuk ahli waris pada waktu pewaris masih hidup tidak dipandang sebagai kewarisan.

\section{Tujuan Pewarisan}

Tujuan kewarisan dalam Islam yaitu :

a. Teraturnya kewajiban dan hak keluarga mayit dan dihormati. Kewajiban untuk mengurus hak-hak adami mayit: mengurus jenazah, melaksanakan wasiat dan menyelesaikan utang piutang. Serta hak keluarga mayit yakni menerimaharta warisan.

b. Menghindari perselisihan antar ahli waris atau keluarga mayit yang ditinggalkan. Menjaga silaturahmi keluarga dari ancaman perpecahan yang disebabkan harta warisan serta memberikan rasa aman dan adil.

c. Terjaganya harta warisan hingga sampai kepada individu yang berhak menerima harta warisan. Memberikan legalitas atas kepemilikan harta warisan.

d. Terciptanya ketentraman hidup dan suasana kekeluargaan yang harmonis.

e. Mencegah terjadinya pertumpahan darah akibat proses pembagian harta warisan.

f. Memberikan rasa keadilan bagi para penerima hak warisan.

${ }^{8}$ Ibid, h. 24

${ }^{9}$ Athoilah, Fikih Waris (Metode Pembagian Waris Praktis), (Bandung: Yrama Widya, 2013), h. 2 
g. Mendistribusikan harta peninggalan secara adil dan merata kepada para pihak anggota keluarga yang menjadi ahli waris.

h. Menghindarkan diri dari perselisihan dan perpecahan, bahkan pertengkaran akibat rebutan harta peninggalan.

i. Dapat memahami hukum-hukum Allah yang berkaitan dengan pembagian harta peninggalan.

j. Terhindar adanya kelangkaan orang yang faham dalam pembagian harta warisan di suatu tempat. ${ }^{10}$

\section{Rukun Kewarisan}

Untuk terjadinya sebuah pewarisan harta, maka harus terpenuhi rukun- rukun waris. Bila ada salah satu dari rukunrukun tersebut tidak terpenuhi, maka tidak terjadi pewarisan. Menurut hukum Islam, rukun-rukun mewarisi ada tiga yaitu:

1. Muwarrits (Pewaris) adalah orang yang telah meninggal dunia dengan meninggalkan harta warisan untuk di bagibagikan pengalihannya kepada para ahli waris. Harta yang dibagi waris haruslah milik seseorang, bukan milik instansi atau negara. Sebab instansi atau negara bukanlah termasuk pewaris.

2. Warits (Ahli Waris) adalah orang-orang yang berhak mendapatkan harta peninggalan si mati, baik di sebabkan adanya hubungan kekerabatan dengan jalan nasab atau pernikahan, maupun sebab hubungan hak perwalian dengan muwarrits. ${ }^{11}$

3. Mauruts (Harta Waris) adalah harta benda yang di tinggalkan oleh si mati yang akan di warisi oleh para ahli waris setelah di ambil untuk biaya-biaya perawatan, melunasi hutang-hutang dan melaksanakan wasiat. Harta pseninggalan ini oleh para faradhiyun di sebut juga dengan tirkah atau turats.

${ }^{10} \mathrm{Jaenal}$ Aripin, Filsafat Hukum Islam: Tasyri dan Syar'i, Jakarta: UIN Jakarta Press, 2006), h. 128.

${ }^{11}$ Fatchur Rahman, Op. Cit., h. 36 


\section{Asas-Asas Hukum Kewarisan Islam}

Berbagai asas hukum ini memperlihatkan bentuk karakteristik dari hukum kewarisan Islam. Adapun asas-asas hukum kewarisan Islam ialah:

1. Asas Integrity (Ketulusan) artinya ketulusan hati, kejujuran, atau keutuhan. Asas ini mengandung pengertian bahwa melaksanakan hukum kewarisan dalam Islam, di perlukan ketulusan hati menaatinya karena terikat dengan aturan yang diyakini kebenaranya (taat pada syariat Islam/ kitab suci Al-Quran surat Ali 'Imran: 85.

2. Asas Ta'abbudi (Penghambaan Diri) adalah melaksanakan hukum waris sesuai syariat Islam adalah bagian dari ibadah kepada Allah swt Sebagai ibadah, dan tentunya mendapatkan berpahala bila ditaati seperti menaati hukum-hukum Islam lainya. (QS. An Nissa': 13-14).

3. Asas Huququl Maliyah (Hak-hak Kebendaan) adalah hakhak kebendaan, dalam arti bahwa hanya hak dan kewajiban terhadap kebendaan saja yang dapat diwariskan kepada ahli waris.

4. Asas Huququn Thabi'iyah (Hak-hak Dasar) adalah hakhak dasar dari ahli waris sebagai manusia. Artinya, meskipun ahli waris itu seorang bayi yang baru lahir atau seorang yang sudah sakit menghadapi kematian sedangkan ia masih hidup ketika pewaris meninggal dunia.

5. Asas Ijbari (Keharusan, Kewajiban) adalah yang mengatur tata cara peralihan secara otomatis harta dari seorang, baik pewaris maupun ahli waris sesuai dengan ketetapan Allah swt. Tanpa tergantung pada kehendak seseorang baik pewaris maupun ahli waris.

6. Asas Bilateral dalam hukum kewarisan berarti seseorang menerima hak atau bagian warisan dari kedua belah 
pihak, dari kerabat keturunan laki-laki dan dari kerabat keturunan perempuan.

7. Asas Individual menyatakan harta warisan dapat dibagi kepada masing-masing ahli waris untuk dimiliki secara perorangan. Dalam pelaksanaanya seluruh harta dinyatakan dalam nilai tertentu, kemudian dibagibagikan kepada ahli waris yang dapat menerimanya menurut kadar bagian masing-masing. (QS. An-Nisaa':8)

8. Asas Keadilan Yang Berimbang mengandung pengertian bahwa harus ada keseimbangan antara hak yang diperoleh seseorang dari harta warisan dengan kewajiban atau beban biaya kehidupan yang harus di tunaikannya. (Qs. Al-Baqarah: 233)

9. Asas Kematian menandakan bahwa peralihan harta seseorang kepada orang lain terjadi setelah seseorang itu meninggal dunia. ${ }^{12}$

10. Asas Membagi Habis Harta Warisan hingga tak tersisa adalah makna dari asas ini.

\section{Sistem Kewarisan Adat Lampung Sai Batin}

Sistem pembagian harta waris yang terjadi di Pasar Tengah Kelurahan Pasar Kota Krui Kecamatan Pesisir Tengah, berdasarkan hasil wawancara dan penjelasan bapak Fhanani Ayub selaku pemuka adat menyatakan bahwa masyarakat Pasar Krui terdiri dari empat suku yaitu :

1. Suku Kampung Dalam. Suku kampung dalam adalah penduduk asli daerah.

2. Suku Anak Sungai. Suku anak sungai berasal dari Pelambang.

3. Suku Semaka. Suku semaka berasal dari Lampung Selatan (Tanggamus ataupun yang berasal dari selat Malak (Melayu).

${ }^{12}$ Abdul Ghofur Anshori, Hukum Kewarisan di Indonesia, (Yogyakarta: Gajah Mada University Press, 2012), h. 32 
4. Suku Pauh. Suku pauh berasal dari Timur Tengah (Arab).

Tiga suku (Suku anak sungai, Suku Semaka dan Suku Pauh) menyatu dengan Suku Kampung Dalam, di dalam melestarikan seni budaya adat Pasar Krui. Sistem adat pasar krui tidak mempunyai kedudukan Dalom, Sai Batin dan Suntan dalam sistem adat pasar krui, karena pasar krui memiliki sistem adat tunggal yaitu sistem adat Suku Kampung Dalam. Terutama dalam hal pembagian harta waris mereka menggunakan sistem mayorat matrilineal (Nuhako Bebai atau menuakan perempuan).

Apabila dibandingkan dengan struktur masyarakat adat Pekon Way Napal yang dipimpin oleh bapak Putrawan Jayadiningrat selaku pemangku adat, dengan menyandang gelar adat sebagai Suntan Pangiran Dalam Simbangan Ratu, berdasarkan hasil wawancara dengan beliau menyatakan bahwa hukum adat adalah hukum yang tidak tertulis, independen, bersifat otonomi tetapi bukan termasuk dalam otonomi daerah dan merupakan suatu hak preogatifnya seorang Suntan. Struktur masyarakat adat atau marga berbeda dengan struktur pemerintahan dalam konteks Negara kesatuan dan demokrasi. Struktruk masyarakat adat atau marga pekon Way Napal dipimpin oleh seorang Suntan yang membawahi 4 (empat) Suku Paksi ditambah dengan Tumenggung. Adapun empat Suku Paksi ini terdiri dari Lamban Lunik, Lamban Balak, Lamban Bandung dan Lamban Dalom.

Adapun fungsi dari empat suku Paksi adalah untuk menyelesaikan masalah yang terjadi atau timbul baik dari masyarakat suku adat dan suku Sai Batin melalui empat suku Paksi tersebut dengan persetujuan Tumenggung. Apabila suatu masalah yang dihadapi tidak selesai dalam tahapan tersebut maka masyarakat suku adat dan suku Sai Batin boleh mengajukan permasalahannya kepada seorang Suntan sebagai pimpinan tertinggi dalam suatu suku Marga. 
Secara struktur dalam marga empat Suku Paksi di atas memiliki garis komando kebawah membawahi 12 suku adat, karena berdirinya suatu marga terdiri dari 12 suku adat dan suku Sai Batin. Adapun yang dimaksud dengan suku adat adalah suku atau kelompok masyarakat yang mendiami suatu pemukiman yang secara historis mereka membawa gelar dari daerah sebelumnya yang kemudian ditetapkan di marga Way Napal. Sedang suku Sai Batin adalah jika ada kelompok masyarakat yang memenuhi syarat dan berdomisili di wilayah Way Napal dan meminta pengakuan untuk menjadi warga adat dengan memalui musyawarah (iragh adat) yang dipimpin oleh seorang Raja yang tidak tunduk kepada suku adat, apabila terjadi permasalahan suku Sai Batini ini langsung menghadap ke Lamban Dalom. Perbedaan yang jelas dan pasti antara suku adat dengan suku Sai Batin adalah dari genggaman, apabila suku adat genggamannya secara turun temurun dan bisa diberlakukan, sedangkan suku Sai Batin sebaliknya.

Dalam suatu suku adat biasanya dipimpin oleh seorang Raja ditetapkan berdasarkan Surat Keputusan (SK) Suntan sebagai pimpinanan tertinggi suku Marga. Dalam Marga Way Napal yang dipimpin oleh Suntan Putrawan Jayadiningrat, membawahi 12 suku marga yang terbagi menjadi 5 (lima) wilayah dan dipimpin oleh seorang Raja, adapun pembagian kelima wilayah tersebut yaitu:

1. Padang Tekukogh, dipimpin oleh Raja Kapitan (Mad Sofyan).

2. Padang Raya, dipimpin oleh Raja Batin Simbangan (Kusairi), Raja Pemuka (Syarif Darmawan), Raja Mengunang (Irawansyah) dan Raja Gemutogh (M. Muksir).

3. Padang Ratu (Way Napal), dipimpin oleh Raja Kapitan (Mad Tahril), Raja Sakti dan Raja Nur (Mad Nur).

4. Padang Haluan, dipimpin oleh Raja Kunci Batin (Waridin) dan Raja Nyata Mangku (Yohan Hasnal). 
5. Padang Negri, dipimpin oleh Raja Duta Marga (Bustan) dan Raja Dalom Mahkota (Alex Iskandar).

Sistem pembagian harta waris yang terjadi di masyarakat Pasar Tengah Kelurahan Pasar Kota Krui Kecamatan Pesisir Tengah menganut sistem mayorat matrilineal atau mengutamakan garis keturunan wanita, tapi dalam hal ini wanita tidak memiliki harta peninggalan secara utuh melainkan hanya sebatas untuk menempati rumah yang menjadi harta peninggalan tersebut. Apabila terjadi kerusakan terhadap rumah yang ditempatinya tidak ada keharusan untuk memperbaiki sendiri, melainkan bisa meminta bantuan kepada anak laki-laki untuk dapat memperbaiki rumah tersebut. Adapun yang menjadi alasan kenapa wanita yang dipilih sebagai penerima harta waris pada masyarakat Pasar Krui, antara lain:

1. Untuk melindungi kedudukan dan kehidupan kaum perempuan (Lamban Tuha).

2. Untuk meningkatkan perekonomian kehidupan keluarga perempuan (Sabah Tuha dan Kebun Tuha).

Sedangkan sistem pembagian harta waris yang dipergunakan oleh masyarakat adat Way Napal, menganut sistem pembagian mayorat patrilineal atau mengutamakan garis keturunan laki-laki, dalam hal ini yang berhak menerima yaitu anak laki-laki tertua. Dalam proses pembagian harta warisnya berdasarkan keputusan orang tua dalam hal ini bapak sebagai pemegang dan pemilik keputusan secara mutlak dalam memutuskan siapa yang berhak untuk mendapatkan harta waris. Tetapi dalam hal ini anak laki-laki tertua tidak boleh meminta harta waris sebelum orang tuanya meninggal, dalam proses pewarisan biasanya bapak sebagai pemegang penuh kekuasan dan keputusan memberikan wasiat baik dalam bentuk tertulis atau lisan kepada istrinya, kemudian setelah ayah meninggal berdasarkan wasiat itulah harta baru dapat diwariskan kepada anaknya dan anak boleh mengelola harta tersebut untuk kepentingan keluarga. Selain anak meminta harta warisan sebelum orang tua meninggal, hal yang 
dapat menghapus anak laki-laki tertua tidak mendapatkan harta warisan karena mandagh (anak laki-laki keluar dari wilayah adat atau anak laki-laki tertua ini tinggal ditempat istri yang berbeda wilayah adatnya).

Alasan mengapa masyarakat adat Way Napal tetap mempertahankan sisitem pembagian harta waris berdasarkan mayorat patrilineal, antara lain :

1. Regenerasi dalam rangka meneruskan jenjang keturunan dan tatanan adat serta kehidupan sosial-budaya masyarakat.

2. Untuk lebih menjaga kerukunan dalam warga adat.

3. Untuk menjamin dan menjaga serta melestarikan hukum waris adat agar tidak punah atau hilang.

Harta yang dapat digolongkan menjadi harta peninggalan atau warisan dalam masyarakat adat Pasar Krui yaitu :

1. Lamban Tuha (Rumah Tua)

2. Kebun Tuha (Kebun Tua)

3. Sabah Tuha (Sawah Tua).

Untuk menentukan siapa yang berhak mendapatkan harta warisan di atas, masyarakat adat Pasar Krui menggunakan sistem musyawarah, musyawarah yang dilakukan antara anggota keluarga dilakukan untuk menentukan siapa yang berhak mendiami rumah, dan mengolah sawah atau kebum. Dalam musyawarah biasanya dipimpin oleh anak laki-laki yang mempunyai tugas untuk menentukan sistem apa yang akan digunakan dalam pembagian harta waris adalah mayorat matrilineal (Nuhako Anak Bebai atau menuakan anak perempuan), dengan cara anak perempuan tersebut diberikan kepercayaan untuk mendiami dan memanfaatkan hasil yang diperoleh dari harta waris, dengan syarat tidak boleh dimiliki secara mutlak (dijual).

Selain sistem musyawarah, masyarakat adat pasar krui juga mengenal sistem lain dalam proses pembagian harta waris, masyarakat boleh menggunakan sistem adat mayorat 
matrilineal atau mayorat patrilineal ataupun menggunakan sistem Hukum Islam (Faraidh). Dari keberagaman sistem yang digunakan oleh masyarakat adat pasar krui ini menunjukkan dan mempertegas bahwa masyarakat diberikan pilihan untuk menggunakan sistem apa dan yang mana dalam proses pembagian harta waris mereka, hal ini juga diperkuat dengan tidak adanya sanksi atau hukuman bagi masyarakat yang tidak menggunakan sistem hukum adat dalam proses pembagian harta waris yang terjadi di pasar krui.

Terdapatnya kesamaan antara harta waris masyarakat Pasar Krui dengan masyarakat Way Napal, harta yang dapat diwariskan pada masyarakat Way Napal, terdiri dari :

1. Kebun (kebon)

2. Sabah (sawah)

3. Lamban Tuha (rumah tua atau rumah induk).

Berdasarkan harta waris tersebut di atas, yang berhak untuk menetukan sistem pembagian harta waris adat adalah pemangku adat (minimal kepala suku adat), sedangkan proses pembagiannya melalui beberapa langkah sebagai berikut:

1. Pembagian harta waris berdasarkan wasiat dan surat wasiat dari pewaris kepada ahli waris, dengan mencantumkan bagian masing-masing sesuai dengan kebijakan pewaris dan urutan ahli waris.

2. Musyawarah keluarga yang melibatkan pemangku adat sebagai saksi atau penengah apabila terjadi masalah dalam proses pembagiannya.

Apabila belum menemukan kesepakatan (putusan) maka pembagian dilakukan berdasarkan hukum adat yang berlaku diwilayah adat. Dalam hal ini Sai Batin atau pemangku adat menjadi eksekutif tunggal dalam pembagian harta waris, yang kemudian hasilnya dituangkan dalam surat keputusan yang dikeluarkan oleh pemangku adat.

\section{Analisis Data}

1. Sistem Pembagian Harta Waris Adat Lampung Sai Batin 
Sistem pewarisan atau jalannya pewarisan adalah cara bagaimana pewaris berbuat untuk meneruskan atau mengalihkan harta kekayaan yang akan ditinggalkan kepada para waris ketika pewaris itu masih hidup dan bagaimana cara warisan itu diteruskan penguasaan dan pemakaiannya atau cara bagaimana melaksanakan pembagian warisan kepada para waris setelah pewaris wafat.

Masyarakat adat Lampung Sai Batin Kab. Pesisir Barat biasanya menggunakan beberapa cara proses pewarisan, diantaranya adalah dengan cara penerusan atau pengalihan dan dengan cara penunjukkan.

a. Penerusan atau pengalihan

Di daerah Lampung penerusan atau pengalihan hak atas kedudukan dan harta kekayaan, biasanya berlaku setelah pewaris berumur lanjut di mana anak tertua lelaki sudah mantap berumah tangga, demikian pula adik-adiknya. Dengan penerusan dan pengalihan hak dan kewajiban sebagai kepala rumah tangga menggantikan ayahnya, maka selama ayah masih hidup, ayah tetap kedudukannya sebagai penasehat dan memberikan laporan dan pertanggungan jawab kekeluargaan.

Termasuk dalam arti penerusan atau pengalihan harta kekayaan tertentu, sebagai dasar kebendaan untuk melanjutkan hidup kepada anak-anak yang akan kawin mendirikan rumah tangga baru, misalnya pemberian atau diberikannya rumah dan pekarangan tertentu, bidang-bidang tanah ladang, kebun atau sawah, untuk anak lelaki atau perempuan yang akan berumah tangga.

b. Penunjukkan

Cara penunjukkan oleh orang tua kepada anakanaknya atau pewaris kepada ahli waris atas harta tertentu, maka berpindahnya penguasaan dan pemilikannya baru berlaku dengan sepenuhnya kepada ahli waris setelah pewaris wafat. 
Apabila orang tua masih hidup, maka ia berhak dan berwenang menguasai harta yang ditunjukkan itu, tetapi di dalam pengurusan atau pemanfaatannya dari harta itu sudah dapat dinikmati oleh orang atau anak yang ditunjuk. Pada masyarakat adat Lampung Sai Batin Kab. Pesisir Barat, biasanya apabila orang tua memberikan sebagian hartanya dengan cara penunjukkan, maka seluruh anakanaknya dikumpulkan.

Berdasarkan penjelasan di atas, Bapak Putrawan Jayadiningrat, S.Pd gelar Suntan Pangiran Dalom Simbangan Ratu, selaku punyimbang pada Marga Way Napal menambahkan penjelasan dengan contoh berikut, bahwa setelah seluruhnya berkumpul, maka si bapak memberikan pernyataan, misalnya sawah yang luasnya satu hektar dan terletak di sini adalah hak untuk anaknya si A, kemudian mobil yang biasa dia pakai untuk anaknya si B. Bila sudah demikian maka jika kelak bapaknya meninggal dunia, barulah si A dan si B berhak atas harta yang diberikan.

Bagi masyarakat adat Lampung Sai Batin Kab. Pesisir Barat selain harta yang sudah diberikan dengan jalan penerusan atau pengalihan dan penunjukkan, maka sisa harta yang tidak dibagi akan dikuasai oleh anak tertua laki-laki, misalnya rumah peninggalan orang tua. Maka walaupun orang tua tidak meninggalkan wasiat atau pesan terhadap harta yang tidak dibagi, kedudukan harta itu secara otomatis akan dikuasai oleh anak tertua laki-laki.

Sedangkan kedudukan anak angkat adat mempunyai tanggung jawab sepenuhnya kepada orang tua adat baik dari aspek tanggung jawab sebagai anak pribadi maupun tanggung jawab atas kedudukan orang tua adat yang meliputi tanggung jawab atas segala harta warisan dan kerabat dari orang tua adat.

Anak laki-laki yang telah diambil menjadi suami tersebut kedudukannya menjadi pengganti anak kandung dan bisa sebagai punyimbang, dalam hal menggunakan harta warisan kedudukan suami isteri adalah sejajar, tetapi walaupun 
hak pakai dari seluruh harta warisan suami isteri sejajar, karena anak laki-laki yang diangkat sebagai anak mentuha ini telah dianggap sebagai pengganti anak kandung, tetap saja kedudukannya suami adalah di tempat si perempuan.

Dalam melakukan perbuatan hukum antara suami dan isteri dalam sistem perkawinan semanda tidak berimbang. Walaupun yang nampak keluar adalah suami, namun dikarenakan pengaruh isteri lebih besar daripada suami, maka kedudukan suami lebih rendah dari isteri, hal mana akan nampak dalam kekerabatan adat dipihak isteri, dimana suami hanya bertindak sebagai pembantu pelaksana, sedangkan kekuasaan adat berada di tangan kerabat isteri, karena dalam hal ini suami hanya sebagai penerus keturunan saja, sampai mendapat anak laki-laki, sedangkan kedudukannya terhadap harta peninggalan tidak ada sama sekali, karena yang berhak sepenuhnya adalah anak laki-laki hasil dari perkawinan itu.

Dalam hal ini apabila si anak wanita yang setelah melakukan perkawinan "ngakuk ragah", beberapa waktu kemudian meninggal dunia tetapi selama berkeluarga itu mereka belum dikaruniai keturunan baik lakilaki ataupun perempuan, berarti hak terhadap harta warisan bagi anak lakilaki yang telah diangkat menjadi anak angkat adat (anak mentuha) hilang, dan putus keturunan hanya sampai disitu saja. Dengan demikian otomatis anak laki-laki tersebut walaupun telah diangkat secara adat dianggap sudah keluar dari kekerabatan keluarga besar isteri.

Di Indonesia, musyawarah keluarga serumah di lingkungan masyarakat parental, patrilineal atau matrilineal merupakan kebiasaan yang berfungsi dan berperanan dalam memelihara dan membina kerukunan hidup kekeluargaan. Di masa sekarang, sengketa harta warisan tidak saja terjadi di kalangan masyarakat parental, tetapi juga terjadi di kalangan patrilineal dan matrilineal, hal mana dikarenakan para anggota masyarakat adat sudah lebih banyak dipengaruhi alam fikiran serba kebendaan, sebagai akibat kemajuan zaman dan 
timbulnya banyak kebutuhan hidup, sehingga rasa malu, rasa kekeluargaan dan tolong-menolong sudah semakin surut.

Dalam pembagian warisan perlu diperhatikan, bahwa harta peninggalan tidak akan dibagi-bagi sepanjang masih diperlukan untuk menghidupi dan mempertahankan berkumpulnya keluarga yang ditinggalkan. Tetapi dalam kenyataannya, seringkali timbulnya sengketa warisan di antara anggota-anggota keluarga yang ditinggalkan, apabila para pihak yang diberi hak untuk menguasai harta peninggalan seringkali menganggap bahwa harta tersebut merupakan hak atau bagian warisnya.

Oleh karena itu, pada masyarakat adat Lampung Sai Batin Kab. Pesisir Barat khususnya di Pekon Way Napal apabila terjadi suatu sengketa, dalam hal penyelesaian masalahnya masyarakat adat selalu mencari jalan keluar dengan cara kekeluargaan dan musyawarah mufakat yang menghasilkan suatu keputusan-keputusan yang dihormati warganya. Dalam hal ini, berdasarkan keterangan yang diperoleh dari H. Marwan Rusli gelar Suttan Pengadilan, selaku tokoh adat di pekon Way Napal, terdapat dua macam musyawarah yang biasanya dilakukan oleh masyarakat adat Lampung Sai Batin Kab. Pesisir Barat, yaitu :

1) Dalam musyawarah keluarga, biasanya dihadiri oleh semua anggota keluarga atau ahli waris, kemudian dikumpulkan disatu rumah keluarga besar, lalu dengan persetujuan bersama di tunjuk satu orang yang dituakan dalam keluarga untuk menjadi juru bicara dalam memimpin musyawarah tersebut. Musyawarah keluarga tersebut juga harus dihadiri oleh ketua adat sebagai salah satu orang yang dapat memberikan saran yang netral tanpa memihak pendapat pihak yang satu dengan pihak yang lainnya. Setelah permasalahan dikemukakan oleh pihak-pihak yang bersengketa, kemudian di cari jalan keluarnya yang terbaik bagi semua pihak. Dalam hal ini peranan ketua adat bertujuan untuk memberikan pendapat baik itu berupa petuah-petuah atau nasehat- 
nasehat dan mengenai tata cara pembagian warisan yang dianggap adil menurut ketentuan adat yang berlaku. Jika dalam musyawarah keluarga tidak terjadi kata sepakat, baru kemudisn permasalahan itu diselesaikan dalam musyawarah adat.

2) Musyawarah Adat (Peradilan Adat). Apabila masih juga terjadi perselisihan mengenai warisan antara pihak yang satu dengan pihak yang lain, maka perkara tersebut dapat dibawa ke dalam musyawarah adat yang dilakukan di balai adat. Dengan dihadiri oleh ketua adat (punyimbang adat) anggota-anggota pemuka adat yang lain dan anggota-anggota kerabat yang bersengketa. Punyimbang adat menjadi juru bicara dalam memimpin musyawarah tersebut, sebagai orang yang dapat memberikan saran yang netral tanpa memihak pendapat pihak yang satu dengan pihak yang lainnya. Setelah permasalahan dikemukakan oleh pihak-pihak yang bersengketa kemudian dicari jalan keluarnya yang terbaik bagi semua pihak. Dalam hal ini peranan punyimbang bertujuan untuk memberikan pendapat baik itu berupa petuah-petuah atau nasehat-nasehat dan mengenai tata cara pembagian warisan yang dianggap adil menurut ketentuan adat yang berlaku.

Bagi masyarakat adat Lampung Sai Batin Kab. Pesisir Barat, sistem musyawarah dan pelaksanaan peradilan adat dapat berlaku menurut tingkatan-tingkatan kekerabatan (serumah, sesuku, sekampung, semarga, antar marga), sebagaimana urutan struktur masyarakat yang bersifat genealogis patrilineal. Apabila ternyata dalam musyawarah adat masih tidak terjadi kesepakatan, diusahakan masalah tersebut jangan sampai diselesaikan melalui jalan peradilan hukum. Karena menurut masyarakat adat Lampung, dibawanya masalah perselisihan sampai ke pengadilan, berarti kehidupan kekerabatan keluarga yang bersangkutan tidak terhormat lagi di mata masyarakat adat. 
Pada masyarakat adat Lampung Sai Batin Kab. Pesisir Barat, khususnya di Pekon Way Napal, sengketa mengenai warisan belum pernah sampai ke pengadilan, karena rasa kekeluargaan yang masih tinggi dan peranan punyimbang masih berpengaruh besar bagi masyarakat adat setempat.

2. Tinjauan Hukum Islam Terhadap Pembagian Harta Waris Adat Lampung Sai Batin

Dalam praktek pembagian warisan keluarga di masyarakat adat Lampung Sai Batin Kab. Pesisir Barat pada prakteknya pembagian harta waris masih tetap menggunakan hukum adat. Sebenarnya dalam al-Qur'an telah dijelaskan tentang bagaimana cara membagi harta itu dengan cara syariat Islam dan secara adil. Allah berfirman dalam al-Qur'an mengenai pembagian harta benda untuk para ahli waris dan orang-orang yang tidak berhak menerima pembagian harta benda tersebut, sebagaimana yang tercantum dalam surat anNisa ayat 11-12 dan 176 yang telah ditentukan bagian-bagian harta waris yang akan diperoleh pewaris.

Dimana laki-laki mendapatkan bagian lebih besar 2:1 daripada perempuan, karena laki-laki memiliki tanggung jawab lebih besar daripada perempuan seperti membayar maskawin dan memberi nafkah terhadap istrinya kelak. Dalam hal ini Islam juga telah mengatur cara-cara menentukan ahli waris yang berazaskan keadilan antara kepentingan anggota keluarga dengan kepentingan agama dan masyarakat. Jumlah keseluruhan ahli waris itu ada 25 (dua puluh lima), yang terdiri dari 15 (lima belas) kelompok lakilaki dan 10 (sepuluh) kelompok perempuan.

Namun di sini terdapat ketidaksesuaian antara sistem pembagian harta waris yang disyari'atkan oleh agama Islam dengan apa yang dipraktekkan di masyarakat adat di Desa Pasar Krui dan Desa Way Napal, Kabupaten Pesisir Barat. Dalam pembagian harta waris Islam mengenai orang yang berhak menerima warisan (ahli waris) dan bagian-bagian yang seharusnya diperoleh oleh ahli waris sudah sangat jelas 
sebagaimana dijelaskan pada paparan di atas, sedangkan dalam pembagian harta waris di Pasar Krui Kec. Pesisir Tengah Kab. Pesisir Barat, Lampung, yang menngunakan pembagian waris adat matrilineal harta waris hanya diperoleh anak perempuan, sesngkan pembagian waris yang terjadi di Pekon Way Napal, yang menggunakan pembagian waris adat patrilineal harta waris hanya diperoleh anak laki-laki pertama, sedangkan bagi ahli waris yang lain tidak mendapatkan warisan. Dalam bagian jumlah ahli waris pun dibagi sesuai dengan rasa keadilan dari anak pertama laki-laki selaku penerima harta waris satu-satunya. Adapun mengenai prosedur dalam mendapatkan warisan, dalam Islam terdapat beberapa syarat yang harus dipenuhi bagi ahli waris :

a. Adanya pewaris, maksud dari pewaris adalah orang yang meninggalkan harta bendanya untuk oarang-orang yang berhak.

b. Orang yang akan menerima warisan.

c. Harta yang ditinggalkan.

Dari paparan di atas diketahui terdapat kesamaan antara syarat yang diatur dengan cara syariat Islam maupun yang dipraktekkan masyarakat di Pekon Pasar Krui dan Pekon Way Napal, Kab. Pesisir Barat.

Sedangkan mengenai penghalang bagi pewaris untuk mendapatkan harta waris terdapat perbedaan, bahwasanya jika dalam Islam yang dapat menghalangi untuk mendapat waris yaitu membunuh, beda agama, dan perbudakan. Namun dalam masyarakat adat Lampung Sai Batin di Pekon Pasar Krui dan Way Napal mengenai halangan untuk mendapatkan warisan yang dipraktekkan yaitu pembunuhan, beda agama, dan perbudakan. Akan tetapi dalam masalah pembunuhan, ahi waris yang terkena kasus pembunuhan tetap mendapatkan bagian dari muwarits setelah mendapatkan maaf dari ahli waris yang lain. Adapun mengenai jumlah bagian ahli waris yaitu hanya sebatas kebutuhan sehari-hari dan jumlahnya sesuai dengan kesepakatan ahli waris yang lain. Masyarakat muslim 
di desa Serupa Indah ini lebih mementingkan kedudukan anak laki-laki sebagai pewaris tunggal dari harta bapaknya karena anak laki-laki dianggap besar tanggung jawabnya. Sedangkan yang terjadi pada masyarakat adat Pasar Krui, yang berhak mendapat harta waris adalah anak perempuan tetapi hanya sebatas menempati dan mengelola saja, tidak bisa dimiliki secara mutlak.

Berdasarkan analisis yang telah dilakukan, sistem pewarisan Islam dengan sistem pewarisan masyarakat adat Lampung terdapat persamaan dan perbedaan antara keduanya yaitu:

a. Pesamaan antara syarat yang diatur dengan cara syariat Islam maupun yang dipraktikkan masyarakat di Pekon Pasar Krui dan Way Napal Kab. Pesisir Barat, yaitu:

1) Pengertian hukum waris baik meurut Islam dan adat mengandung pengertian yang sama.

2) Subyek hukum waris baik menurut Islam dan adat sama, yaitu: pewaris dan ahli waris.

3) Harta warisnya sama-sama yang dikurangi dengan biaya-biaya sewaktu pewaris sakit, biayan pengurusan jenazah, pembayaran hutang yang dimiliki jenazah selama masih hidup.

4) Ahli waris baik dari Islam ataupun adat sama-sama berasal dari keluarga terdekat.

b. Perbedaan yang terdapat pada sistem pewarisan Islam dan adat Lampung Pepadun yaitu sebagai berikut:

1) Pada hukum waris adat memiliki sistem pewarisan kolektif dan kewarisan mayorat, sedangkan hukum Islam tidak mengenal kedua sistem tersebut.

2) Pada hukun waris Islam yang menjadi ahli waris sangat jelas dan terperinci dalam surat an-Nisa 11-12 dan ayat 176, sedangkan dalam adat Lampung Sai Batin hanya anak laki-laki tertua yang menjadi ahli waris dan perempuan tertua tpi perempuan hanya sebatas mengelola dan menmpati saja. 
3) Dalam hukum waris Islam besarnya bagian dari harta warisan yang didapat oleh ahli waris sangat jelas dan dirinci, sedangkan pada hukum waris adat Lampung belum jelas mengenai besarnya bagian yang didapat oleh waris dari harta warisan.

4) Dalam hukum waris Islam mengenai penghalang bagi pewaris untuk mendapat harta waris yaitu pembunuh, beda agama, dan budak. Sedangkan dalam hukum waris adat Lampung Sai Batin yaitu pembunuh, beda agama, dan budak. Tetapi dalam masalah pembunuhan, ahi waris yang terkena kasus pembunuhan tetap mendapatkan bagian dari muwarits setelah mendapatkan maaf dari ahli waris yang lain.

c. Masyarakat adat Lampung menggunakan sistem pewarisan adat dibandingkan Islam, meski sebagain besar masyarakat Lampung Sai Batin di Pekon Pasar Krui dan Way Napal Kab. Pesisir Barat beragama Islam, namun sistem pewarisan yang digunakan adalah sistem mayorat perempuan dan laki-laki tertua, karena di Pekon Pasar Krui dan Way Napal Kab. Pesisir Barat masih kental dengan aturan adat yang berlaku sampai saat ini. Selain itu hal ini juga disebabkan kurangnya kesadaran mereka mengenai hukum waris Islam sebagai bagian aturan agama Islam, sehingga mereka lebih memilih hukum adat. Karena masyarakat adat Lampung Sai Batin menggunakan sistem pewarisan adat yaitu mayorat perempuan dan laki-laki maka hal ini bertentangan dengan Islam. Meski demikian, masyarakat adat Lampung Sai Batin di Pekon Pasar Krui dan Way Napal Kab. Pesisir Barat tidak mengabaikan hak dan kewajiban ahli waris serta syarat mewaris. Hanya saja masyarakat adat Lampung Sai Batin belum begitu memahami aturan agama Islam yang membagi harta waris secara adil. 


\section{Kesimpulan}

Dari uraian yang telah dipaparkan di atas tentang kewarisan masyarakat adat Lampung Sai Batin Pesisir Barat dalam perspektif Hukum Islam, maka dapat disimpulkan sebagai berikut:

1. Sistem yang digunakan oleh masyarakat adat lampung Sai Batin Pesisir Barat terbagi menjadi dua bentuk, yaitu:

a. Masyarakat adat yang berada di Pasar Krui menggunakan sistem pembagian mayorat matrilinel atau mengutamakan keturunan ibu. Tetapi dalam hal ini perempuan atau wanita yang mendapatkan waris hanya berhak untuk menempati rumah dan mengelola kebun saja, tidak berhak untuk menjual harta tersebut. Apabila dalam keluarga tidak mempunyai anak perempuan maka anak laki-laki juga berhak untuk mendapatkan harta waris tersebut, hal ini dikarenakan keputusan siapa yang berhak untuk mendapatkan harta waris adalah orang tua terutama ayah.

b. Masyarakat adat yang berada di Way Napal menggunakan sistem pembagian mayorat patrilineal atau mengutamakan garis keturunan bapak. Dalam sistem patrilineal ini keputusan mutlak dimiliki oleh pewaris sebagai pemilik dan pemegang keputusan secara mutlak. Kepada siapa harta akan dibagikan dan berapa besar bagiannya ditentukan oleh keputusan pewaris. Adapun cara yang digunakan dalam pembagian ini adalah dengan menggunakan wasiat..

2. Masyarakat adat Lampung menggunakan sistem pewarisan adat. Pesisir Barat beragama Islam, namun sistem pewarisan yang digunakan adalah sistem mayorat perempuan dan laki-laki tertua, karena di Pekon Pasar Krui dan Way Napal masih kental dengan aturan adat yang berlaku sampai saat ini. Selain itu hal ini juga disebabkan kurangnya kesadaran mereka mengenai hukum waris Islam sebagai bagian aturan agama Islam, sehingga mereka lebih memilih hukum adat. 


\section{Daftar Pustaka}

Anshori, Abdul Ghofur, Hukum Kewarisan di Indonesia, Yogyakarta: Gajah Mada University Press, 2012

Aripin, Jaenal, Filsafat Hukum Islam: Tasyri dan Syar'i, Jakarta: UIN Jakarta Press, 2006

Athoilah, Fikih Waris (Metode Pembagian Waris Praktis), Bandung: Yrama Widya, 2013

Hadikusuma, Hilman, Hukum Kekerabatan Adat, Jakarta: Fajar Agung, 1978

Prodjodikoro. R. Wirjono, Hukum Warisan di Indonesia, Jakarta: Sumur Bandung, 1980

Shabuni, al-, Muhammad Ali, Pembagian Waris Menurut Islam, Terj. Basalamah, Jakarta: Gema Insani Press, 1995

Shobuni, al-, Muhammad Ali, al-Mawarits fi al-Syariat alIslamiyyah, diterjemahkan Hamdan Rasyid, Hukum Kewarisan, Menurut Al-Qur'an dan Sunnah, Jakarta: Dar AlKutub Al-Islamiyah, 2005

Syarifuddin, Amir, Garis-Garis Besar Fiqh, Jakarta: Prenada Media, 2005

Umam, Dian Khairul, Fiqih Mawaris, Bandung: Pustaka Setia, 2006

Yunus, Mahmud, Kamus Arab-Indonesia, Jakarta: PT. Hidakarya Bandung, 1990 